\title{
SALT RETENTION IN CIRRHOSIS OF THE LIVER ${ }^{1}$
}

\author{
By ALLAN V. N. GOODYER, ARNOLD S. RELMAN, F. DOUGLAS LAWRASON, 2 \\ AND FRANKLIN H. EPSTEIN
}

\author{
(From the Department of Internal Medicine, Yale University School of Medicine, \\ New Haven)
}

(Submitted for publication November 4, 1949; accepted, April 10, 1950)

\section{INTRODUCTION}

The retention of salt in patients with cirrhosis of the liver has been interpreted for many years as a physiologic renal response to the formation of edema and ascites in conformity with the principles of Starling as a consequence of hypoproteinemia and portal hypertension $(1,2)$. It has been thought that the salt-containing fluid which escapes from the plasma is rendered "unavailable" for excretion, or that transudation tends to produce a deficit in the functional plasma volume, which, in an as yet unexplained way, stimulates renal tubular reabsorption of salt and water (3).

However, it has been suggested recently that the retention of fluid and salt in patients with cirrhosis of the liver is a direct renal response to anti-diuretic (4) and anti-saluretic (5) substances produced as a consequence of faulty hepatic metabolism. According to this view, portal hypertension and hypoalbuminemia may not be primarily responsible for the retention of fluid, but may be chiefly concerned with its localization. The evidence which has been offered in favor of this hypothesis is, however, not entirely convincing. It is derived chiefly from experiments on cirrhotics in which administration of salt increased the rate of formation of ascites and edema (5-9). However, the subjects of these experiments were allowed free access to water, so that salt was, in effect, being given as an approximately isotonic solution which, in the normal subject, is quickly distributed throughout the extracellular space and excreted very slowly. In the cirrhotic patient, salt administered as isotonic saline might escape from the functional circulation as ascites or edema before much could be excreted. Consequently, in order to ascribe the retention of a

\footnotetext{
1 Aided by a grant from the James Hudson Brown Memorial Fund of the Yale University School of Medicine.

2 James Hudson Brown Research Fellow.
}

salt load by such a patient to a renal abnormality, the salt must be given in such a way as to produce and maintain an increased concentration of the serum sodium, and thus to provide a direct, prolonged stimulus for the renal excretion of sodium.

The experiments of this report were therefore undertaken, (1) to determine the responses of a group of cirrhotics to administration of hypertonic salt solution under conditions of hydropenia when exogenous water was unavailable for dilution of the serum sodium or for the formation of edema and ascites, and (2) to amplify the meager data on glomerular filtration and renal blood flow in cirrhotics with the syndrome of salt retention.

\section{Subjects}

\section{METHODS}

Experiments were performed upon two groups of patients: Group I was composed of two cirrhotics who had neither ascites nor edema (cases 4 and 5) and three patients hospitalized for minor orthopedic and gastrointestinal disabilities (cases 1-3). Group II was composed of six patients with cirrhosis of the liver proved by biopsy, who had ascites with or without peripheral edema. In five of these cases (cases 6-10) ascites was slowly accumulating in spite of dietary restriction of salt. In one patient (case 11) ascitic reaccumulation had been almost stopped by a salt-free diet and mercurial therapy. This case, however, will be considered separately because he received an injection of Mercuhydrin 48 hours before the experimental day. All subjects were free of any clinical manifestation of cardiac or renal disease. Pertinent clinical and laboratory data are summarized in Table III.

\section{Procedure}

Further preliminary evaluation of renal function was made by means of mannitol and para-aminohippurate clearances, conducted according to standard techniques $(10,11)$, using indwelling bladder catheters only in those cases where incomplete evacuation of the bladder was anticipated (cases 6, 8, 9, 11).

Each patient was maintained on a salt-free diet containing less than a gram of salt per day for at least four days (usually more) prior to administration of the saline infusion. Body weight, water intake, urine flow, and 
salt excretion were measured and blood specimens for analyses of electrolyte concentrations were drawn during consecutive periods as indicated in Table II. On the morning of the experimental day, an infusion of $500 \mathrm{cc}$. of $5 \%$ sodium chloride was administered at the rate of $5 \mathrm{cc}$./ min. All subjects were deprived of food and water for 12 hours before the infusion, and for six to eight hours thereafter, after which the previous salt-free diet and unrestricted water intake were resumed. Urine collections were made at about two-hourly intervals for six to eight hours during water deprivation and at less frequent intervals during the subsequent period of rehydration. Blood specimens were collected from an antecubital vein in the arm opposite that used for the infusion. They were obtained just before and about three to five minutes after the infusion, and at the end of the period of water deprivation. In most cases, observations were continued for 48 hours after the infusion.

\section{Analytical methods}

Mannitol concentrations in serum and urine were determined by the method of Smith and associates (10), as modified by Barker and Clark (12) and by Elkinton (13). Para-aminohippurate concentrations in serum and urine were measured by the method of Smith, and co-workers (14). Sodium and potassium were measured with a flame photometer by the method of Hald (15).

\section{RESULTS}

Determinations of mannitol and para-aminohippurate clearances during consecutive clearance periods are listed in Table I. In only one cirrhotic was the glomerular filtration rate definitely below normal (case 10). Renal plasma flows were subnormal in this case, and borderline in two others (cases 6 and 9).

The infusion of $500 \mathrm{cc}$. of $5 \%$ sodium chloride solution produced the following effects during the period of continued water deprivation (Table II).$^{3}$

1) The concentration of serum sodium increased 5-16 meq./1. (average, 10 meq./1.) in both groups of patients.

2) The concentration of serum potassium remained either unchanged or decreased slightly during the infusions in the four subjects (cases $4,9,10,11)$ in which adequate measurements were made.

${ }^{3}$ In summarizing the data regarding urinary excretion, case 11 (Group IIb) will be treated separately because of a mercurial injection given 48 hours before the infusion. It is probable that though the rate of sodium excretion of this patient had reached a very low value in the interim, some residual effect from the mercurial was present at the time of the saline infusion.
3) Urine flows increased slightly in all cases of Group I and in three cases of Group IIa; they declined in two cases of Group IIa (cases 6 and 7).

4) The concentrations of sodium in the urines of the patients of Group I increased from initial values of $7-82$ meq./1. to maxima of $176-267$ meq./1., whereas those of the patients of Group IIa increased from initial values of $0.74-2.17$ meq./1. to maxima of $4.6-102$ meq./1. ${ }^{4} \mathrm{U} / \mathrm{P}$ ratios for sodium exceeded 1.0 in all patients of Group I, and in no cases of Group II, during and after the saline infusions.

5) Partly as a result of increased urine flow, but principally due to increased concentrations of sodium in the urine, the rate of sodium excretion (Figure 1) increased greatly in the cases of Group I to maxima of $190-1147 \mathrm{micro}-\mathrm{eq} . / \mathrm{min}$. (averages, 141-649 micro-eq./min.), ${ }^{5}$ and in the

\pm The concentration of 137 meq./1. in the urine of case 10 occurred after readministration of water.

${ }^{5}$ Averages refer to excretory rates for the period between the beginning of the infusion and rehydration; maxima, to excretory rates for the fractional collections during the same period.

TABLE I

Renal clearances of mannitol (GFR) and para-aminohippurate $(E R P F)$ during consecutive clearance periods

\begin{tabular}{|c|c|c|c|c|}
\hline Subject & $\begin{array}{c}\text { Clearance } \\
\text { period }\end{array}$ & $\begin{array}{c}\text { GFR } \\
c c . / \min . \\
1.73 \mathrm{~m}^{2}\end{array}$ & $\begin{array}{c}\text { ERPF } \\
c c . / m i n . \\
1.73 m^{2}\end{array}$ & $\mathrm{FF}^{*}$ \\
\hline $\begin{array}{l}\text { Group I } \\
\text { 1) A. M. }\end{array}$ & $\begin{array}{l}1 \\
2\end{array}$ & $\begin{array}{r}106 \\
96\end{array}$ & $\begin{array}{l}597 \\
559\end{array}$ & $\begin{array}{l}.17 \\
.17\end{array}$ \\
\hline 2) M. Pa. & $\begin{array}{l}1 \\
2\end{array}$ & $\begin{array}{l}95 \\
90\end{array}$ & $\begin{array}{l}868 \\
697\end{array}$ & $\begin{array}{l}.11 \\
.13\end{array}$ \\
\hline 4) $\mathrm{V} . \mathrm{V}$ & 1 & & 593 & 一 \\
\hline $\begin{array}{l}\text { Group IIa } \\
\text { 6) M. M. }\end{array}$ & $\begin{array}{l}1 \\
2\end{array}$ & $\begin{array}{l}113 \\
133\end{array}$ & $\begin{array}{l}388 \\
448\end{array}$ & $\begin{array}{l}.29 \\
.30\end{array}$ \\
\hline 7) L. X. & $\begin{array}{l}1 \\
2\end{array}$ & $\begin{array}{l}103 \\
100\end{array}$ & $\begin{array}{l}464 \\
520\end{array}$ & $\begin{array}{l}.22 \\
.19\end{array}$ \\
\hline 8) A. B. & $\begin{array}{l}1 \\
2\end{array}$ & $\begin{array}{l}122 \\
125\end{array}$ & $\begin{array}{l}635 \\
658\end{array}$ & $\begin{array}{l}.19 \\
.19\end{array}$ \\
\hline 9) D. D. & $\begin{array}{l}1 \\
2\end{array}$ & $\begin{array}{l}85 \\
91\end{array}$ & $\begin{array}{l}443 \\
455\end{array}$ & $\begin{array}{l}.19 \\
.20\end{array}$ \\
\hline 10) J. D. & $\begin{array}{l}1 \\
2\end{array}$ & $\begin{array}{l}60 \\
60\end{array}$ & $\begin{array}{l}358 \\
238\end{array}$ & $\begin{array}{l}.17 \\
.25\end{array}$ \\
\hline $\begin{array}{l}\text { Group IIb } \\
\text { 11) T. L. }\end{array}$ & 1 & 94 & 526 & .18 \\
\hline
\end{tabular}

$* \mathrm{FF}$, filtration fraction $=\frac{\mathrm{GFR}}{\mathrm{ERPF}}$. 
patients of Group IIa to maxima of only 2.5-113 hours, except in three cases $(1,2$, and 8$)$ in which micro-eq./min. (averages, $1.7-88$ micro-eq./min.). it followed maximum urine flow by as much as Maximum sodium excretion coincided with maxi- three to four hours (case 2). The results of the mum urine flow during the first two post-infusion experiment on case 11 (Group IIb) resembled

TABLE II

Experimental data for consecutive periods of urine collection

\begin{tabular}{|c|c|c|c|c|c|c|c|c|c|c|}
\hline \multirow{2}{*}{ Subject } & \multirow{2}{*}{ Period } & \multirow{2}{*}{ Time } & \multirow{2}{*}{ Wt. } & \multicolumn{2}{|c|}{ Serum $†$} & \multicolumn{5}{|c|}{ Urine } \\
\hline & & & & $\mathrm{Na}$ & $\mathbf{K}$ & Flow & & & & \\
\hline Group I & no.* & mins. & kilos & meq./l. & meq. $/ l$. & $c c . / \min$ & meq./l. & $\begin{array}{c}\text { micro-eq./ } \\
\text { min.f }\end{array}$ & meq./l. & $\begin{array}{l}\text { micro-eq./ } \\
\text { min. } .\end{array}$ \\
\hline $\begin{array}{l}\text { 1) A. M. } \\
\text { Arthritis }\end{array}$ & $\begin{array}{l}1-w \\
2-w \\
3 \\
4 \S \\
5 \\
6 \\
7-w \\
8-w\end{array}$ & $\begin{array}{r}1440 \\
1440 \\
164 \\
178 \\
88 \\
87 \\
203 \\
720\end{array}$ & $\begin{array}{l}54.0 \\
53.0\end{array}$ & $\begin{array}{l}131 \\
139 \\
149 \pi \\
148 \\
136\end{array}$ & & $\begin{array}{l}0.54 \\
0.56 \\
0.49 \\
2.19 \\
2.33 \\
2.07 \\
1.14 \\
0.70\end{array}$ & $\begin{array}{l}37.6 \\
27.6 \\
43.0 \\
195 \\
209 \\
246 \\
232 \\
154\end{array}$ & $\begin{array}{c}20.3 \\
15.5 \\
21.1 \\
427 \\
487 \\
509 \\
265 \\
108\end{array}$ & $\begin{array}{l}67.3 \\
68.2 \\
67.3 \\
85.0 \\
49.0 \\
32.6 \\
54.4\end{array}$ & $\begin{array}{c}37.7 \\
33.4 \\
147 \\
198 \\
101 \\
37.2 \\
38.1\end{array}$ \\
\hline $\begin{array}{l}\text { 2) M. Pa. } \\
\text { Arthritis }\end{array}$ & $\begin{array}{l}1-w \\
2-w \\
3 \\
48 \\
5 \\
6 \\
7-w \\
8-w\end{array}$ & $\begin{array}{r}1440 \\
1440 \\
112 \\
168 \\
115 \\
120 \\
205 \\
720\end{array}$ & $\begin{array}{l}59.1 \\
59.0\end{array}$ & $\begin{array}{l}135 \\
138 \\
148 \pi \\
145 \\
136\end{array}$ & $\begin{array}{l}4.6 \\
4.99 \\
4.4\end{array}$ & $\begin{array}{l}0.89 \\
0.49 \\
0.31 \\
1.82 \\
1.61 \\
1.42 \\
0.83 \\
0.47\end{array}$ & $\begin{array}{l}15.6 \\
16.5 \\
15.8 \\
195 \\
219 \\
267 \\
248 \\
199\end{array}$ & $\begin{array}{c}13.9 \\
8.08 \\
4.90 \\
355 \\
353 \\
379 \\
206 \\
93.5\end{array}$ & $\begin{array}{l}67.4 \\
83.4 \\
52.5 \\
98.0 \\
63.2\end{array}$ & $\begin{array}{c}33.0 \\
25.9 \\
95.6 \\
158 \\
89.7\end{array}$ \\
\hline $\begin{array}{l}\text { 3) J. M. } \\
\text { Ulcer (duod.) }\end{array}$ & $\begin{array}{l}1-w \\
2-w \\
3 \\
4 \S \\
5 \\
6 \\
7-w \\
8-w\end{array}$ & $\begin{array}{r}1440 \\
1440 \\
146 \\
134 \\
115 \\
120 \\
205 \\
720\end{array}$ & $\begin{array}{l}77.8 \\
77.5\end{array}$ & $\begin{array}{l}132 \\
135 \\
151 \uparrow \\
149 \\
136\end{array}$ & & $\begin{array}{l}1.04 \\
0.76 \\
0.79 \\
0.82 \\
1.26 \\
0.88 \\
0.76 \\
0.42\end{array}$ & $\begin{array}{c}27.8 \\
23.4 \\
6.5 \\
98.5 \\
151 \\
176 \\
162 \\
197\end{array}$ & $\begin{array}{c}28.9 \\
17.8 \\
5.14 \\
80.8 \\
190 \\
155 \\
123 \\
82.7\end{array}$ & & \\
\hline $\begin{array}{l}\text { 4) V. V. } \\
\text { Cirrhosis; no } \\
\text { edema or ascites }\end{array}$ & $\begin{array}{l}1-w \\
2-w \\
3 \\
4 \S \\
5 \\
6 \\
7 \|-w\end{array}$ & $\begin{array}{r}720 \\
720 \\
165 \\
185 \\
107 \\
78 \\
905\end{array}$ & $\begin{array}{l}78.1 \\
77.8 \\
79.5\end{array}$ & $\begin{array}{l}139 \\
143 \pi \\
144\end{array}$ & $\begin{array}{l}4.7 \\
4.3 \rrbracket \\
4.1\end{array}$ & $\begin{array}{l}4.78 \\
4.00 \\
1.08 \\
2.78 \\
2.08 \\
1.79\end{array}$ & $\begin{array}{l}4.97 \\
10.6 \\
34.8 \\
173 \\
196 \\
205\end{array}$ & $\begin{array}{r}23.8 \\
42.4 \\
37.6 \\
481 \\
408 \\
367\end{array}$ & $\begin{array}{r}9.0 \\
47.2 \\
37.5 \\
65.0 \\
55.7\end{array}$ & $\begin{array}{c}36.0 \\
51.0 \\
104 \\
135 \\
99.7\end{array}$ \\
\hline $\begin{array}{l}\text { 5) M. Po. } \\
\text { Cirrhosis; no } \\
\text { edema or } \\
\text { ascites }\end{array}$ & $\begin{array}{l}1-w \\
2-w \\
3 \\
4 \S \\
5 \\
6 \\
7 \\
8-w \\
9-w \\
10-w\end{array}$ & $\begin{array}{r}720 \\
720 \\
50 \\
96 \\
19 \\
115 \\
130 \\
70 \\
860 \\
1440\end{array}$ & $\begin{array}{l}70.4 \\
71.0\end{array}$ & $\begin{array}{l}138 \\
150 \text { ๆ } \\
146 \\
138 \\
132\end{array}$ & $\begin{array}{l}4.9 \\
4.6\end{array}$ & $\begin{array}{l}1.10 \\
0.50 \\
1.50 \\
2.62 \\
5.26 \\
4.00 \\
2.46 \\
1.25 \\
0.61 \\
0.47\end{array}$ & $\begin{array}{c}31.6 \\
13.7 \\
81.5 \\
195 \\
218 \\
212 \\
204 \\
205 \\
45.6 \\
35.7\end{array}$ & $\begin{array}{c}34.8 \\
6.85 \\
122 \\
511 \\
1147 \\
848 \\
502 \\
256 \\
27.8 \\
16.8\end{array}$ & $\begin{array}{c}32.6 \\
14.8 \\
128 \\
45.7 \\
33.7 \\
43.2 \\
63.2 \\
64.1 \\
44.6 \\
25.7\end{array}$ & $\begin{array}{c}35.9 \\
7.40 \\
192 \\
120 \\
177 \\
173 \\
156 \\
80.1 \\
27.2 \\
12.1\end{array}$ \\
\hline Group IIa & & & & & & & & & & \\
\hline $\begin{array}{l}\text { 6) M. M. } \\
\text { Cirrhosis with } \\
\text { ascites, edema }\end{array}$ & $\begin{array}{l}1-w \\
2-\dot{w} \\
3 \\
4 \S \\
5 \\
6 \\
7-w \\
8 \|-w \\
9-w\end{array}$ & $\begin{array}{r}665 \\
715 \\
147 \\
193 \\
190 \\
245 \\
300 \\
480 \\
1440\end{array}$ & $\begin{array}{l}80.4 \\
79.5 \\
\\
79.2 \\
80.0 \\
79.8\end{array}$ & $\begin{array}{l}126 \\
127 \\
136 \Upsilon \\
133 \\
126 \\
134\end{array}$ & & $\begin{array}{l}0.60 \\
0.85 \\
0.75 \\
0.53 \\
0.24 \\
0.42 \\
0.32 \\
\\
0.36\end{array}$ & $\begin{array}{l}0.92 \\
0.97 \\
0.76 \\
4.62 \\
2.56 \\
4.46 \\
1.98 \\
\\
\\
\\
\end{array}$ & $\begin{array}{l}0.55 \\
0.82 \\
0.57 \\
2.45 \\
0.61 \\
1.87 \\
0.63 \\
\\
0.86\end{array}$ & $\begin{array}{r}57.6 \\
45.2 \\
65.7 \\
\\
102\end{array}$ & $\begin{array}{l}49.0 \\
33.9 \\
34.8 \\
\\
42.8\end{array}$ \\
\hline
\end{tabular}


TABLE II (continued

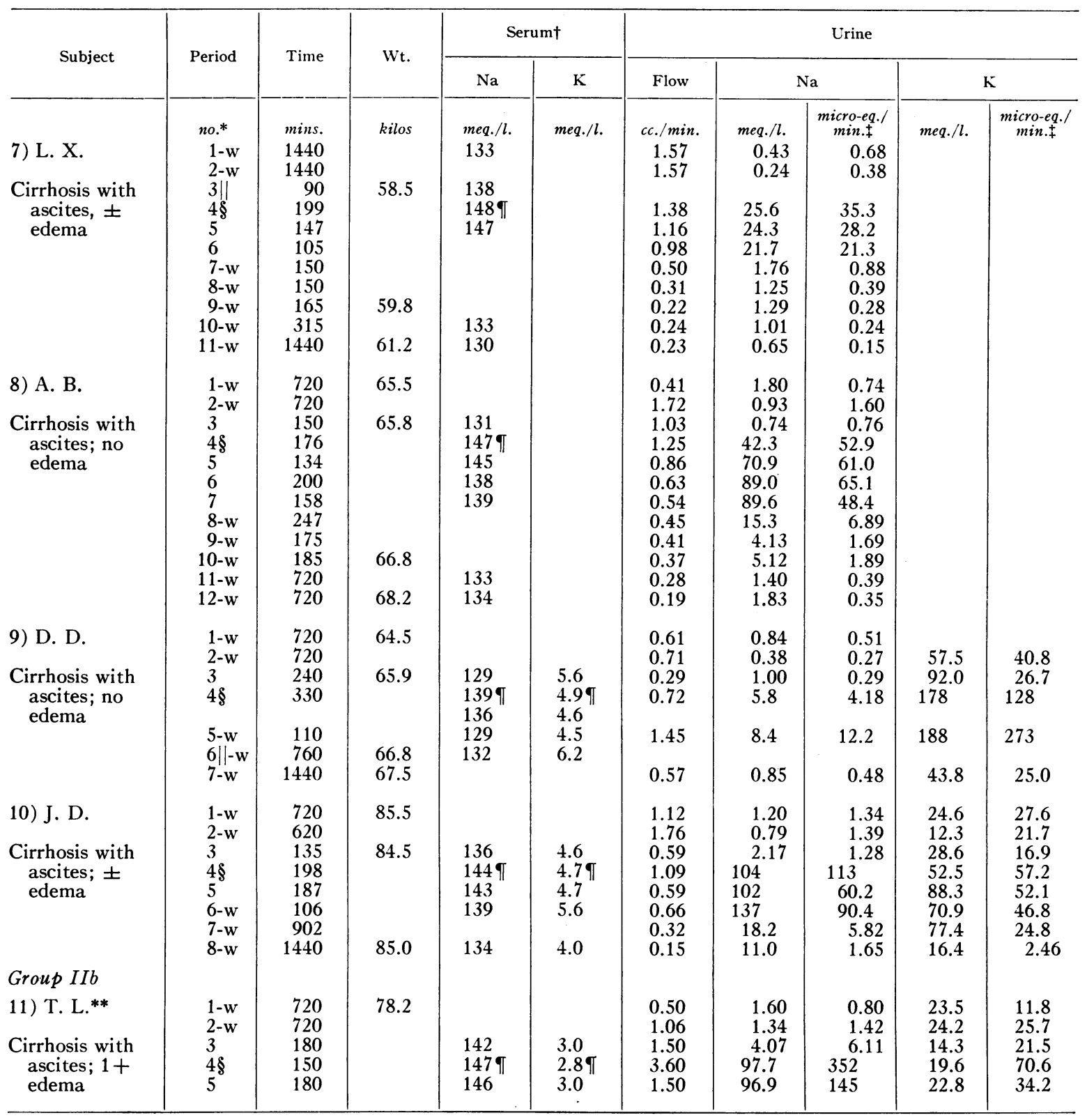

* Periods in which water p.o. was allowed are marked -w.

+ Values at the end of the corresponding period.

$\ddagger 1$ meq. equals 1000 micro-eq.

$\$$ Saline infusion administered in the first part of this period.

II Urine collections incomplete.

I Values at the end of the infusion of saline.

** A mercurial was injected about 48 hours before the first period.

those of Group I in that urinary excretion of sodium increased to a maximum of 352 microeq./min. (av. 239 micro-eq./min.).

6) In the patients of Group I and IIb, potassium excretion in the urine increased during and after the saline infusion mainly as a result of increased urine flow, except in case 5 in which the rates of excretion of both sodium and potassium were anomalously high in the pre-infusion period. Potassium excretion increased in the three cases 
of Group IIa for which adequate data were obtained, mainly as a result of increased concentration of potassium in the urine.

Rehydration by administration of water by mouth $a d$. $l i b$. six to eight hours after the saline infusion produced the following effects (Table II) :

1) After about six hours, the concentration of serum sodium had fallen in all cases to its original level. The rapidity of the fall is exemplified in cases $5,9,10$, and 11 in whom after ingestion of 1000-1300 cc. of water, the concentration of serum sodium had fallen to the pre-infusion level in a period of 70-110 minutes.

2) Partly as a result of a decline in urine flow, but principally owing to a decrease of the concentration of sodium in the urine, the rate of excretion of sodium $^{6}$ declined during the rehydration period (Figure 1) to average rates of 45 143 micro-eq./min. (maxima of 123-365 micro-

${ }^{6}$ Data are incomplete for cases 4,6 , and 9. eq./min.) in the cases of Group I, and to average rates of $0.4-14.8 \mathrm{micro}-\mathrm{eq} . / \mathrm{min}$. (maxima of 0.9 90 micro-eq./min.) in the cases of Group IIa. This occurred in spite of the fact that only a part of the administered sodium had been excreted at the beginning of this period $(12-54 \%$ by cases of Group I ; $0.2-10 \%$ by cases of Group IIa), or at the end of this period (32-68\% by cases of Group I ; $4-12 \%$ by cases of Group II).$^{6}$ This fall in sodium excretion may not have been immediate. In cases 5,9 , and 10 , in which the shortest initial periods following the beginning of water ingestion were obtained, urinary concentration of sodium remained the same or increased during the first two hours, and in cases 9 and 10, urine flow and sodium excretion also increased (Figure 1).

3) Data regarding potassium excretion and concentrations of serum potassium during the rehydration period are incomplete. Potassium excretion increased in one case (case 9) and decreased in three others (cases 1,5 , and 10). The

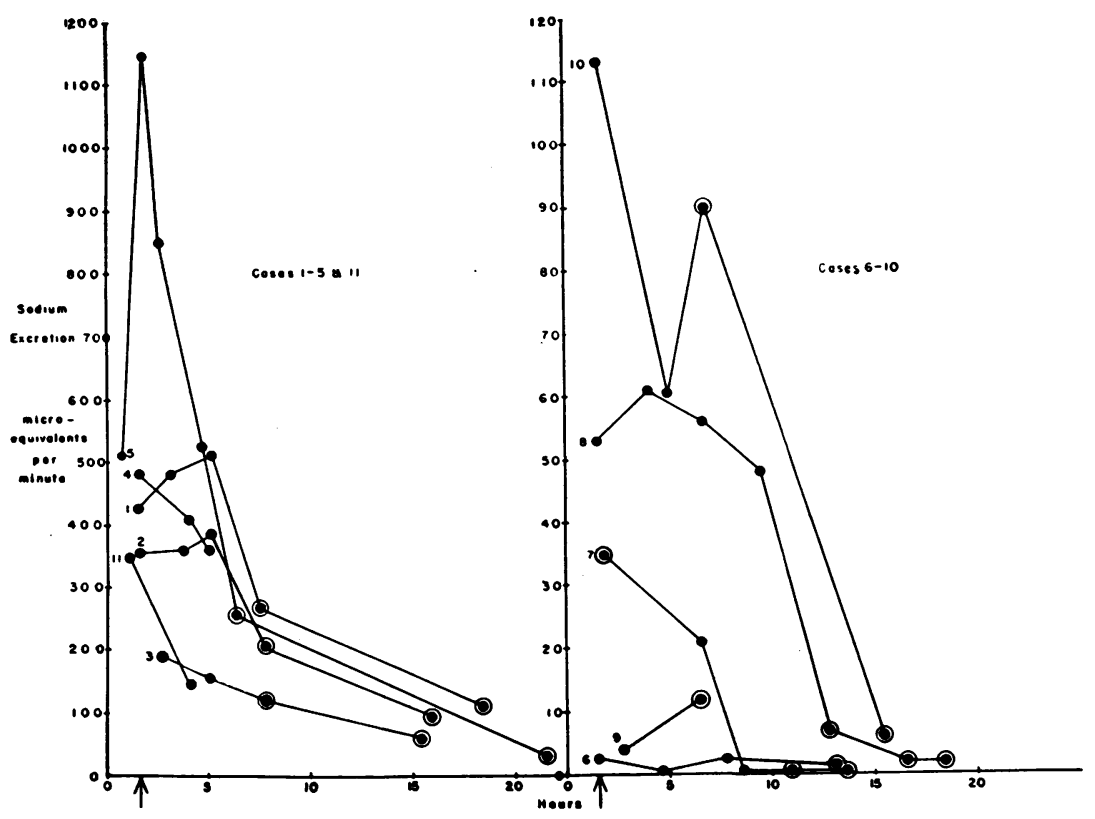

Fig. 1. Rates of Excretion of Sodium in the Urine During and Following the Administration of $500 \mathrm{cc}$. of $\mathbf{5 \%}$ Saline Intravenously

1) Note that the scale used for the cases of Group $I$ is 10 times larger than that used for the cases of Group II.

2) The arrows mark the ends of the saline infusions which were begun at zero time.

3) Each dot represents the rate of sodium excretion during a single period of urine collection and is plotted at the midpoint of the period.

4) The plain dots represent periods during which water by mouth was withheld; the circled dots, periods during which water was ingested. 


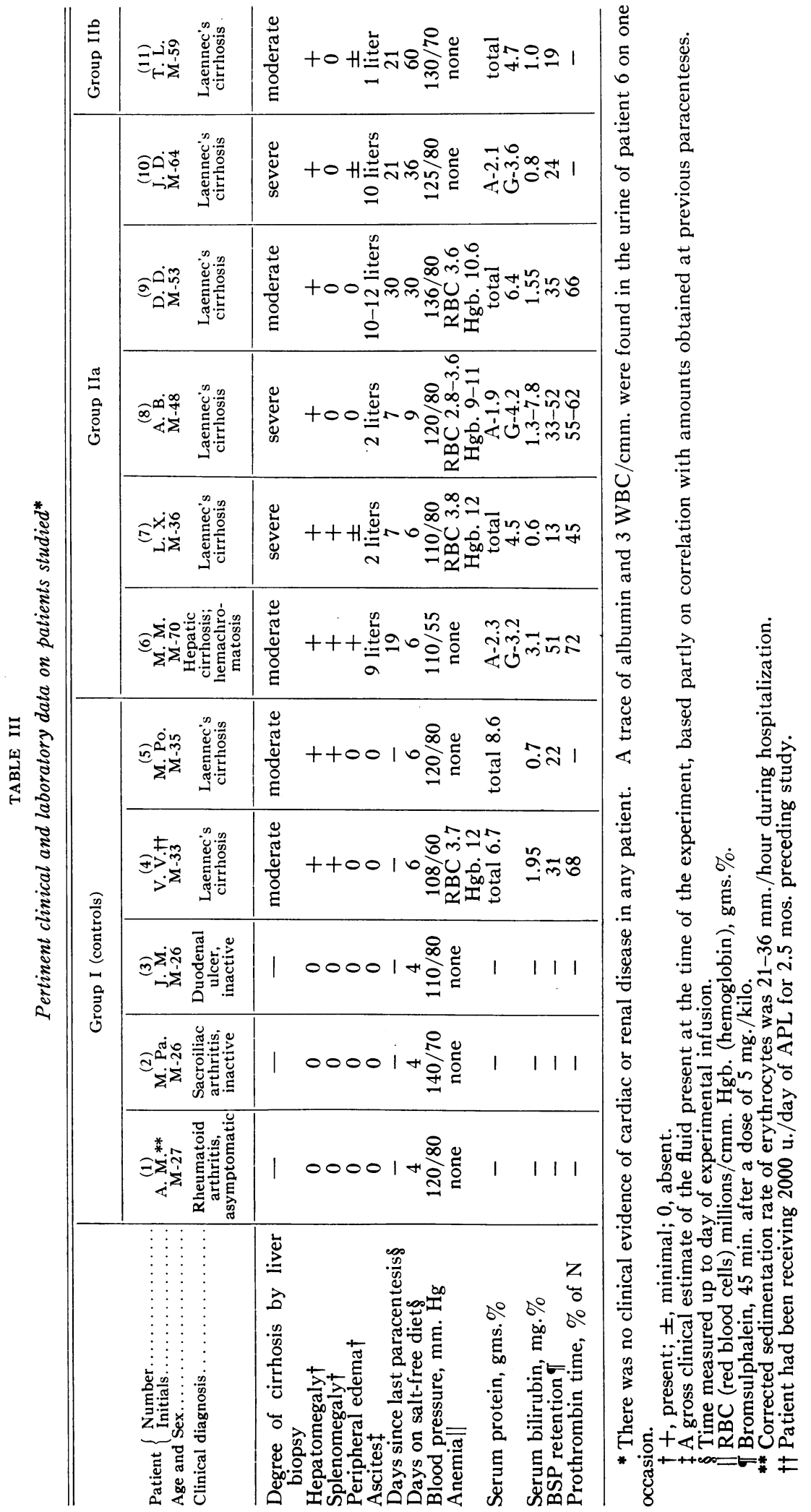


concentration of potassium in the serum rose in the three cases in which it was measured.

\section{DISCUSSION}

When the concentration of sodium in the extracellular fluid is increased by the infusion of hypertonic saline in normal subjects, urine flow and the concentration and rate of excretion of sodium in the urine increase markedly, thereby tending to reduce the concentration of sodium in the serum and extracellular space toward normal (16). The experiments of Group I conformed in general to this pattern and indicated that the renal response to the infusion of hypertonic saline was not prevented by preliminary water and salt deprivation in the subjects of this study. The cases of Group II, on the other hand, excreted only hypertonic urines which tended to increase their hypernatremia; in this respect they resembled the patients with congestive heart failure studied by Futcher and associates (17).

In the normal subject, the diuresis produced by hypertonic saline is continued long after the initially elevated glomerular filtration rate has returned to normal (18). This fact supports the hypothesis that the increased excretion of sodium affected by hypertonic solutions is at least in part a direct response to increased extracellular (and intracellular) tonicity (3). In the experiments of this report, the decrease in sodium excretion following ingestion of water, associated with fairly precise restoration of the serum sodium to the preinfusion value, would suggest that while an increased serum sodium concentration may not be solely responsible for initiating a hypertonic saline diuresis, it is primarily responsible for the maintenance of such a diuresis. These observations also support the thesis that the effects of salt administered to a patient allowed free access to water rapidly become equivalent to the effects of isotonic saline (see Introduction).

The major portion of the administered sodium ${ }^{\text {? }}$ was distributed throughout the extracellular space as an increment in the concentration of sodium, the average value of which (10 meq./1.) did not differ between the patients of Groups I and II. In both groups, consequently, the potential saluretic stimulus of this increment was of the same mag-

\footnotetext{
7 Except for the sodium required to make isotonic the
} water of the infusion. nitude. Furthermore, the administered salt was "available" to the kidney for excretion so long as the serum sodium remained increased. The striking absence of significant natriuresis in the patients of Group IIa, therefore, indicated that the mechanism for the renal excretion of administered salt was defective.

The importance of transient changes in renal hemodynamics in these experiments cannot be evaluated, because the clearance data of Table I were obtained a few days before the saline infusions and therefore are not directly applicable to the periods of these infusions. However, the syndrome of sodium retention was clinically obvious in patients $6,7,8$, and 9 at a time when their mannitol and PAH clearances were within normal limits. The retention of sodium at this time was clearly referable, therefore, to an increased renal tubular reabsorption of salt, the stimulus for which remained obscure. Other observers have found both normal (19) and reduced (20) values for glomerular filtration rate and renal blood flow in cirrhotics with ascites.

Since exogenous water was withheld during the first of the post-infusion periods, the differences between the responses of Groups I and IIa were not attributable to "primary" retention of water (4). On the other hand, within the experimental group, the smallest changes in the renal excretion of sodium were observed in the two patients (cases 6 and 9) with the lowest concentrations of serum sodium both before and after the infusions. These findings would suggest either $a$ ) that an increase in the concentration of the serum sodium above the normal value may be a slightly more effective stimulus for the renal excretion of salt than the same increase from a subnormal value, or $b$ ) that antidiuretic influences may have been directly responsible both for the initially low concentrations of serum sodium and for the slight differences between the renal responses of these two patients and those of the other patients of Group IIa.

Increased excretion of potassium has been observed following administration of a variety of sodium salts in hypertonic solution (21-23), usually in association with increasing urine flows and sodium excretion. In the experiments of this report, the excretion of potassium changed in gross correlation with the excretion of sodium except in 
case 9 in which potassium excretion increased greatly while sodium excretion increased only minimally. It has been suggested that changes in potassium excretion may be caused by shifts of potassium out of cells as a result of cellular dehydration (24). Since the serum sodium increased equally in Groups I and IIa, equal changes in cellular hydration, cellular content of potassium, and urinary excretion of potassium might have been expected. However, the changes in potassium excretion in cases 6,10 , and 11 were considerably less than those observed in the control subjects and in case 9. Potassium excretion in these experiments was therefore influenced by other factors than cellular hydration or the excretion of sodium.

\section{SUM MARY}

1. Five hundred cc. of $5 \%$ saline were infused into normal adults and into patients with cirrhosis, most of whom had normal glomerular filtration rates (mannitol) and renal plasma flows ( $\mathrm{p}$-aminohippurate). All subjects were deprived of food and water for 12 hours before the infusion and for six to eight hours thereafter.

2. The concentrations of serum sodium rose about 10 meq./1. during the infusions in all experiments, and remained elevated during the subsequent period of water deprivation, during which time the normal subjects and two cirrhotics without ascites or edema excreted $12-54 \%$ of the administered sodium. The concentrations of sodium in their urines increased to as much as 267 meq./1. and their rates of sodium excretion increased greatly. In contrast, during the same period, the cirrhotics with edema and/or ascites excreted $0.2-10 \%$ of the administered sodium. The concentrations of sodium in their urines increased to a maximum of 102 meq./1., and their rates of sodium excretion increased only minimally.

3. Potassium excretion increased in most patients coincidentally with the natriuresis, but was not consistently related to the magnitude of the latter.

4. These results are interpreted as evidence of a specific impairment of the renal mechanism for the excretion of administered sodium in cirrhotics with edema and/or ascites.

5. The clearance data indicate the probability that dietary sodium is retained by the kidneys of these patients as a result of its increased tubular reabsorption, the stimulus for which remains obscure.

\section{ACKNOWLEDGMENTS}

We are indebted to the staff of the United States Veterans' Hospital at Newington, Connecticut for their cooperation in the study of many of the cases of this report.

\section{BIBLIOGRAPHY}

1. Post, J., and Patek, A. J., Jr., Serum proteins in cirrhosis of the liver. I. Relation to prognosis and to formation of ascites. Arch. Int. Med., 1942, 69, 67.

2. Bjørneboe, M., Brun, C., and Raaschou, F., Colloid osmotic pressure in chronic hepatitis. Arch. Int. Med., 1949, 83, 539.

3. Peters, J. P., The significance of serum sodium. McGill Med. J., 1949, 18, 130.

4. Ralli, E. P., Robson, J. S., Clarke, D., and Hoagland, C. L., Factors influencing ascites in patients with cirrhosis of the liver. J. Clin. Invest., 1945, 24, 316.

5. Faloon, W. W., Eckhardt, R. D., Cooper, A. M., and Davidson, C. S., The effect of human serum albumin, mercurial diuretics, and a low sodium diet on sodium excretion in patients with cirrhosis of the liver. J. Clin. Invest., 1949, 28, 595.

6. Kriss, B., and Pollak, L., Ueber die Chlorausscheidung bei Leberkranken nach Belastung mit verschiedenen Chloriden. Wien. klin. Wchnschr., 1927, 40, 1251.

7. Blum, L., and Carlier, P., Le traitement de l'ascite de la cirrhose du foie par le chlorure de calcium. Presse méd., 1928, 36, 241.

8. Layne, J. A., and Schemm, F. R., The use of high fluid intake and a low-sodium acid-ash diet in the management of portal cirrhosis with ascites. Gastroenterology, 1947, 9, 705.

9. Kunkel, H. G., Eisenmenger, W. J., and Ahrens, E. $\mathrm{H}$., Jr., Effect of rigid $\mathrm{Na}$ restriction in patients with cirrhosis of the liver and ascites. J. Clin. Invest., 1949, 28, 794.

10. Smith, W. W., Finkelstein, N., and Smith, H. W., Renal excretion of hexitols (sorbitol, mannitol, and dulcitol) and their derivatives (sorbitan, isomannide, and sorbide) and of endogenous creatininelike chromogen in dog and man. J. Biol. Chem., 1940, 135, 231.

11. Chasis, H., Redish, J., Goldring, W., Ranges, H. A., and Smith, H. W., The use of sodium $p$-aminohippurate for the functional evaluation of the human kidney. J. Clin. Invest., 1945, 24, 583.

12. Barker, H. G., and Clark, J. K., Effect of paraamino-hippurate on mannitol determinations by periodate-iodide-thiosulfate method. Proc. Soc. Exper. Biol. \& Med., 1947, 64, 120.

13. Elkinton, J. R., The volume of distribution of mannitol as a measure of the volume of extracellular 
fluid, with a study of the mannitol method. J. Clin. Invest., 1947, 26, 1088.

14. Smith, H. W., Finkelstein, N., Aliminosa, L., Crawford, B., and Graber, M., The renal clearances of substituted hippuric acid derivatives and other aromatic acids in dog and man. J. Clin. Invest., 1945, 24, 388.

15. Hald, P. M., The flame photometer for the measurement of sodium and potassium in biological materials. J. Biol. Chem., 1947, 167, 499.

16. Baird, M. M., and Haldane, J. B. S., Salt and water elimination in man. J. Physiol., 1922, 56, 259.

17. Futcher, P. H., and Schroeder, H. A., Studies on congestive heart failure; impaired renal excretion of sodium chloride. Am. J. Med. Sc., 1942, 204, 52.

18. Dean, R. F. A., and McCance, R. A., Renal responses of infants and adults to administration of hypertonic solutions of sodium chloride and urea. J. Physiol., 1949, 109, 81.

19. Patek, A. J. Jr., Mankin, H., Colcher, H., Lowell, A., and Earle, D. P., Jr., The effects of intravenous injection of concentrated human serum albumin upon blood plasma, ascites, and renal functions in three patients with cirrhosis of the liver. J. Clin. Invest., 1948, 27, 135 .

20. Leslie, S. H., Johnson, B., and Ralli, E. P., Renal clearances in patients with cirrhosis of the liver, with and without ascites. J. Clin. Endocrinol., 1949, 9, 682.

21. Burnett, C. H., Burrows, B. A., Commons, R. R., The lack of correlation between glomerular filtration rate and serum electrolyte concentration changes, urinary electrolyte excretion, or edema formation, following sodium loads in subjects with normal kidneys, glomerulonephritis, and the nephrotic syndrome. J. Clin. Invest., 1949, 28, 773.

22. Rapoport, S., West, C. D., and Brodsky, W. A., Excretion of solutes and osmotic work during osmotic diuresis of hydropenic man. The ideal and the proximal and distal tubular work; the biological maximum of work. Am. J. Physiol., 1949, 157, 363.

23. Wolf, A. V., and Ball, S. M., Effect of intravenous sodium sulfate on renal excretion in the dog. Am. J. Physiol., 1950, 160, 353.

24. Elkinton, J. R., and Winkler, A. W., Transfers of intracellular potassium in experimental dehydration. J. Clin. Invest., 1944, 23, 93.

\section{ERRATUM}

In the article entitled, "Mechanisms of Edema Formation in Chronic Experimental Pericarditis with Effusion," in the May 1950 issue, on page 530, second column, the first word in line 20 should read "hypovolemia" instead of "hypervolemia." 